\title{
Diversity of autoantibodies in patients with antimitochondrial antibody and their diagnostic value
}

\author{
S A MCMILLAN,* JOAN M ALDERDICE, $†$ C M McKEE, \\ M E CALLENDER,§T T FULTON,§ MARGARET HAIREף
}

From the *Immunology Laboratory and the †Department of Histopathology, Belfast City Hospital, the Departments of $\ddagger$ Medicine, \Microbiology and Immunobiology, The Queen's University of Belfast, and the $\S R o y a l$ Victoria Hospital, Belfast, Northern Ireland

SUMMARY A retrospective analysis of clinical and laboratory features of 102 patients, whose sera contained antibody to mitochondria, showed that primary biliary cirrhosis was diagnosed in $50 \%$ of them. Immunofluorescence showed that the sera of the patients with primary biliary cirrhosis all had the M2 antimitochondrial antibody staining pattern. A new staining pattern, designated M2(1), which could be mistaken for the M2 pattern, was not found in any patients with either primary biliary cirrhosis or chronic active hepatitis.

Other serological variables such as antibody to mitochondria in IgM class, to multiple nuclear dots, and to the XR antigen, were associated with primary biliary cirrhosis, and taken in association with antimitochondrial antibody of M2 type, contribute to the diagnosis of the disease.

Although the aetiology of primary biliary cirrhosis is uncertain, it has many features of an autoimmune disease, including the presence of circulating immune complexes, abnormalities in the complement system and in cellular immunity, and the association with other autoimmune diseases, as well as the presence of various types of autoantibodies, especially antimitochondrial antibodies. ${ }^{1}$ The incidence of antimitochondrial antibody in patients with primary biliary cirrhosis, diagnosed on the basis of suggestive clinical history, cholestatic liver function tests, and a raised serum IgM value, has varied from $83-99 \% .^{2-5}$ The presence of antimitochondrial antibody is of uncertain importance, its specificity for primary biliary cirrhosis being between 11 and $49 \% .^{6-9}$ Antimitochondrial antibodies are also found in the sera of patients with other liver conditions, including chronic active hepatitis and cryptogenic cirrhosis and in patients with clinical but no biochemical evidence of liver disease. ${ }^{2}$ They are also found in the sera of patients who have rheumatological and endocrine autoimmune disorders and in subjects without any clinically apparent disease. ${ }^{4910}$ Using indirect immunofluorescence, the M2 type of antimitochondrial antibody seems to be strongly associated with primary biliary cirrhosis, ${ }^{11}$ while other types (M1, M3, M5, M6) have been detected in the sera of patients with a wide variety of condi-

Accepted for publication 30 July 1986 tions. ${ }^{11-13}$ In addition, two antibodies to nuclear components have also been described in primary bili- $\Omega$ ary cirrhosis - namely, antibody to centromere which is a marker for the CREST syndrome, ${ }^{14}$ and an antibody that gives a staining pattern of nuclear? dots $^{15}$ or atypical discrete specks. ${ }^{16}$

The incidence of patients in the greater Belfast area, whose sera contained antimitochondrial antibody, increased from seven patients per 1000 patient samples in 1981 to 26 per 1000 patient samples in 1985 , and most of these were referred from general medical units. This is probably a reflection of the increased use of autoimmune serological screening tests rather than a true increase in antimitochondrial antibody or an improved sensitivity of laboratory tests. The increasing incidence and uncertain clinical importance of antimitochondrial antibody prompted us to examine retrospectively the clinical and laboratory features of patients whose sera gave an antimitochondrial antibody staining pattern by indirect immunofluorescence and to investigate whether the presence of other autoantibodies and serum factors help in the diagnosis of primary biliary cirrhosis.

\section{Material and methods}

A retrospective investigation was made of the clinical and laboratory details of 102 patients from the greater Belfast area, whose sera, obtained over a period of eight years, contained antimitochondrial 
antibody at a titre of $1 / 20$ or greater when tested by indirect immunofluorescence. The group comprised 91 women and 11 men with an average age at first detection of antimitochondrial antibody of 60 years. The sera from all of the patients were hepatitis B surface antigen (HBsAg) negative.

\section{SEROLOGICAL STUDIES}

Sera obtained from these patients were stored at $-20^{\circ} \mathrm{C}$. The serum samples were coded and reexamined (without knowledge of the clinical diagnosis, liver history, liver function tests, or serum IgM values) for the presence and titre of autoantibodies, including antimitochondrial antibody subtypes. Autoantibodies were detected by indirect immunofluorescence using various substrates, which included rat liver, kidney, stomach and heart, calf retina, and human thyroid gland, and the titres of autoantibodies were detected in IgG and IgM classes using fluorescein labelled antihuman immunoglobulin conjugates (Dako Ltd, UK). Antimitochondrial antibody subtypes, as defined by indirect immunofluorescence, were determined using composite tissue and fresh sections of rat kidney cut to show renal cortex and medulla, and the staining patterns were compared with patterns obtained with known antimitochondrial antibody types M1, M2, and M5 sera obtained from Dr GF Bottazzo, Immunology Department, Middlesex Hospital, London. HEp2 cells were used as substrate to detect the presence of various nuclear and cytoplasmic autoantibodies. $^{15}$ Antibodies against soluble cellular antigens were detected and identified by counterimmunoelectrophoresis (CIE) ${ }^{17}$ using saline extracts of rabbit and calf thymus powder (Pelfreez Biologicals, Arkansas, USA), a preparation of human spleen nuclei, ${ }^{18}$ and a cellular preparation of Wi12 cells. ${ }^{19}$ The identification of antibodies detected was done using lines of identity with reference sera obtained from the Centres for Disease Control, Atlanta, USA. Antibody against $\mathrm{XR}$ and $\mathrm{XH}$ was detetected by CIE, using extracts of rabbit thymus and human spleen as a source of XR and XH antigens, respectively. ${ }^{15}$ Con- trol sera containing antibody to XR and XH and antibody giving a multiple nuclear dot pattern were obtained from Dr RM Bernstein. Concentrations of ds-DNA were assayed using the Farr technique (AntiDNA kit assay, Amersham International, UK). Antibody to cardiolipin (VDRL antigen) was detected using the quantitative slide flocculation test (Wellcome Diagnostics, UK). Immunoglobulin $\mathbf{M}$ values were also assayed in the patients' sera by radial diffusion using Nor-Partigen IgM plates (Behring Diagnostics, Hounslow, UK).

\section{STA TISTICS}

The results were analysed using the independent $t$ test, the Mann-Whitney Rank test, and the $\chi^{2}$ test. The conventional level of significance, $p<0.05$, was used for all comparisons.

\section{Results}

\section{CLINICAL DIAGNOSIS OF PATIENTS}

Based on the clinical and biochemical findings at presentation and follow up and on the histological appearances of the needle liver biopsy specimens, primary biliary cirrhosis was diagnosed in 51 of the 102 patients, chronic active hepatitis in five, and cryptogenic cirrhosis in one patient. In a further six patients in whom liver biopsy was not carried out the clinical diagnoses were Gilbert's syndrome, subclinical viral hepatitis, fulminant hepatic failure, and alcoholic liver disease in one patient and chronic liver disease of unknown aetiology in two patients. In 39 patients there was no clinical evidence of liver disease and various diagnoses were made (table 1 ). ${ }^{9}$

\section{ANTIMITOCHONDRIAL ANTIBODIES AND SUBTYPES}

The sera from the 102 patients contained antimitochondrial antibody, which gave three distinct staining patterns on rat tissues by immunofluorescence. The first corresponded to the M2 subtype described by Baum and Berg, ${ }^{11}$ giving strong fluorescence staining of distal tubules and a

Table 1 Clinical diagnosis of patients with different antimitochondrial antibody subtypes

\begin{tabular}{|c|c|c|c|c|c|}
\hline \multirow[b]{2}{*}{ Clinical diagnosis } & \multirow{2}{*}{$\begin{array}{l}\text { Total } \\
\text { No }\end{array}$} & \multirow{2}{*}{$\begin{array}{l}\text { No with } \\
\text { liver biopsy }\end{array}$} & \multicolumn{3}{|c|}{ Antimitochondrial antibody subtypes (\%) } \\
\hline & & & $M 2$ & $M 2(1)$ & MS \\
\hline $\begin{array}{l}\text { Primary biliary cirrhosis } \\
\text { Chronic active hepatitis } \\
\text { Other liver disease } \\
\text { Scleroderma } \\
\text { Rheumatoid arthritis } \\
\text { Other connective tissue disease } \\
\text { Endocrine disorders } \\
\text { Miscellaneous disorders } \\
\text { No diagnosis } \\
\text { Total }\end{array}$ & $\begin{array}{r}51 \\
5 \\
7 \\
4 \\
5 \\
5 \\
7 \\
15 \\
3 \\
102\end{array}$ & $\begin{array}{r}51 \\
5 \\
1 \\
0 \\
0 \\
0 \\
0 \\
0 \\
0 \\
57\end{array}$ & $\begin{array}{l}51(100) \\
5(100) \\
6(86) \\
2(50) \\
5(100) \\
3(60) \\
2(29) \\
10(67) \\
2(67) \\
86\end{array}$ & $\begin{array}{l}0 \\
0 \\
1(14) \\
1(25) \\
0 \\
0 \\
3(43) \\
1(7) \\
0 \\
6\end{array}$ & $\begin{array}{l}0 \\
0 \\
0 \\
1(25) \\
0 \\
2(40) \\
2(29) \\
4(27) \\
1(33) \\
10\end{array}$ \\
\hline
\end{tabular}


slightly weaker staining of proximal tubules and collecting ducts, a granular appearance on rat hepatocytes, and strong uniform staining of rat gastric parietal cells (fig 1 ). The second pattern, designated M2(1), consisted of staining of only the distal tubules and collecting tubules, without staining of the proximal tubules (fig 2). The rat hepatocytes showed weak diffuse staining and the gastric parietal cells showed either weak or moderate staining. A third pattern, which corresponded to the M5 type of antimitochondrial antibody, as described by Labro et al, ${ }^{20}$ was identified by its characteristic appearance on rat kidney, in which proximal tubules in the outer cortex (P1 and P2) were much more brightly stained than the distal tubules, and there was no staining of gastric parietal cells (fig 3 ). The use of calf retina, rat heart, or Hep2 cells did not help discriminate between antimitochondrial antibody subtypes but provided good substrates for detecting antimitochondrial antibody. When the patients were subdivided by their antimitochondrial antibody types, $86(84 \%)$ had the M2 type, six (6\%) the M2(1) type, and $10(10 \%)$ the M5 type (table 2). Although all patients who were diagnosed as having primary biliary cirrhosis or chronic active hepatitis had the M2 pattern, various other "non-liver disease" diagnoses made up the remainder of patients ( 24 of 86 with M2 antimitochondrial antibody. Of these 24 patients, eight

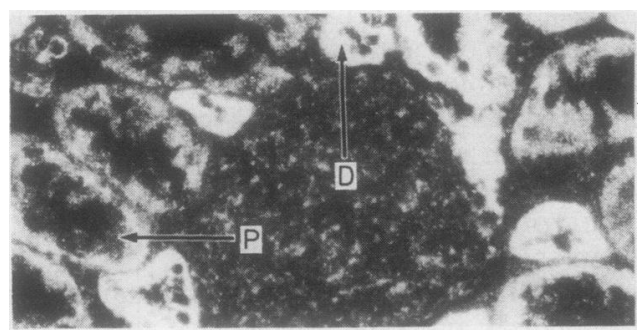

Fig 1 Immunofluorescence staining pattern of antimitochondrial antibody type $M 2$ on rat kidney sections. Staining of both distal and proximal tubules. $\times 340 . P=$ proximal convoluted tubules; $D=$ distal convoluted tubules.

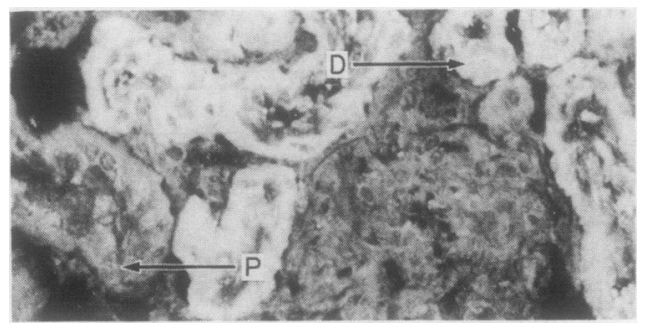

Fig 2 Immunofluorescence staining pattern of antimitochondrial antibody type M2(1) on rat kidney sections. Staining of both distal tubules only. $\times 340 . P=$ proximal convoluted tubules; $D=$ distal convoluted tubules.

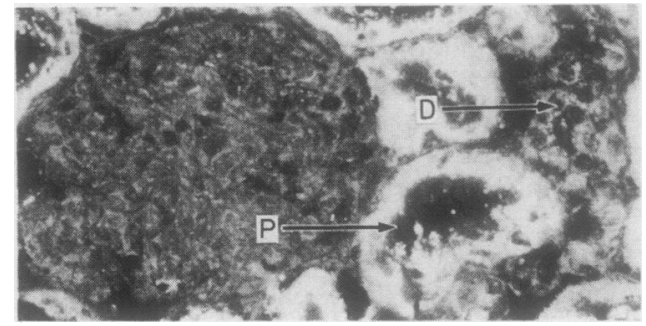

Fig 3 Immunofluorescence staining pattern of antimitochondrial antibody type M5 on rat kidney sections. Staining of proximal tubules only. $\times 340 . P=$ proximal convoluted tubules; $D=$ distal convoluted tubules.

had raised alkaline phosphatase and IgM activities and values, four had raised alkaline phosphatase activity only, and a further nine had raised IgM values only. The six patients whose sera gave antimitochondrial antibody pattern M2(1) had mostly endocrine disorders and none had primary biliary cirrhosis or chronic active hepatitis. Patients with the M5 pattern had a variety of mainly autoimmune conditions and did not have any apparent liver disease.

FURTHER TESTS ON SERA FROM PATIENTS WITH M2 ANTIMITOCHONDRIAL ANTIBODY

Other antibodies

There was a higher incidence of antinuclear antibody and smooth muscle antibody in the group with prf mary biliary cirrhosis than the group with non-liver disease, although this difference was not significant (table 3). The use of HEp2 cultured cells as substrate increased the detection of antinuclear antibody and enabled different antinuclear antibody patterns to be observed: these included homogeneous nuclear, fine speckled nuclear, nuclear dot, multiple nuclear dot, centromere, homogeneous nucleolar, speckled nucleolar and rim nucleolar patterns. In the patients with the multiple dot pattern the number of dots per nucleus varied between five and 15, and there was a significant difference in the incidence of antibody to multiple nuclear dots in the patients with primary biliary cirrhosis compared with those without primary biliary cirrhosis (with primary biliary cirrhosis 21 of 51 or $41 \%$ : without primary biliary cirrhosis zero of $35, p=0.004)$. A correlation was not found, however, between the number of dots per nucleus and any clinical or laboratory finding. Antibody to centromere was found in both the groups with and without primary biliary cirrhosis; most of these patients had scleroderma. $^{14}$ Four different antibodies were detected which reacted against solúble cellular extracts. Antibodies to Ro and $\mathrm{La}$ were detected in similar numbers in patients with and without primary biliary cirrhosis, while antibody to XH was found in 
Table 2 Immunofluorescence intensities on rat composite tissue of various antimitochondrial antibodies found in sera of 102 patients studied

\begin{tabular}{|c|c|c|c|c|c|c|c|c|}
\hline \multirow{2}{*}{$\begin{array}{l}\text { Antimitochondrial } \\
\text { antibody } \\
\text { subtype }\end{array}$} & \multirow[b]{2}{*}{$\begin{array}{l}\text { Liver } \\
\text { hepatocyte }\end{array}$} & \multicolumn{5}{|l|}{ Kidney } & \multicolumn{2}{|l|}{ Stomach } \\
\hline & & $\begin{array}{l}\text { Proximal } \\
\text { tubules I }\end{array}$ & $\begin{array}{l}\text { Proximal } \\
\text { tubules } 2\end{array}$ & $\begin{array}{l}\text { Proximal } \\
\text { tubules } 3\end{array}$ & $\begin{array}{l}\text { Distal } \\
\text { tubules }\end{array}$ & $\begin{array}{l}\text { Collecting } \\
\text { tubules }\end{array}$ & $\begin{array}{l}\text { Parietal } \\
\text { cell }\end{array}$ & $\begin{array}{l}\text { Chief } \\
\text { cell }\end{array}$ \\
\hline $\begin{array}{l}\text { M2 } \\
\text { M2(1) } \\
\text { M5 }\end{array}$ & $\begin{array}{l}+t \\
+ \\
+\end{array}$ & $\begin{array}{l}t+ \\
- \\
+t+\end{array}$ & $\begin{array}{l}t+ \\
- \\
+t+\end{array}$ & $\begin{array}{l}+t \\
- \\
+t\end{array}$ & $\begin{array}{l}+t+ \\
+t \\
t\end{array}$ & $\begin{array}{l}+++ \\
++ \\
-\end{array}$ & $\begin{array}{l}++t \\
+t \\
+\end{array}$ & $\begin{array}{l}+ \\
\pm \\
\pm\end{array}$ \\
\hline
\end{tabular}

P1, P2, P3 = first, second, and third part of proximal tubule.

Table 3 Incidence of autoantibodies in patients within M2 group

\begin{tabular}{|c|c|c|c|c|c|c|c|c|}
\hline \multirow[b]{2}{*}{$\begin{array}{l}\text { Patient groups } \\
\text { (No in group) }\end{array}$} & \multicolumn{8}{|c|}{ Percentage of patients with antibody to: } \\
\hline & $\begin{array}{l}\text { Antinuclear* } \\
\text { antibody }\end{array}$ & $\begin{array}{l}\text { Smooth* } \\
\text { muscle } \\
\text { antibody }\end{array}$ & $\begin{array}{l}\text { Antinucleart } \\
\text { antibody }\end{array}$ & Centromeret & $\begin{array}{l}\text { Multiple } \dagger \\
\text { nuclear } \\
\text { dots }\end{array}$ & $R o_{+}^{+}$ & $L a_{+}^{+}$ & $X R_{+}^{+}$ \\
\hline $\begin{array}{l}\text { Primary biliary cirrhosis }(51) \\
\text { Other liver disease (11) } \\
\text { Non-liver disease (24) }\end{array}$ & $\begin{array}{l}31 \\
18 \\
15\end{array}$ & $\begin{array}{l}41 \\
36 \\
19\end{array}$ & $\begin{array}{l}48 \\
27 \\
29\end{array}$ & $\begin{array}{r}6 \\
0 \\
12\end{array}$ & $\begin{array}{r}41 \\
0 \\
0\end{array}$ & $\begin{array}{r}10 \\
9 \\
8\end{array}$ & $\begin{array}{l}2 \\
6 \\
8\end{array}$ & $\begin{array}{r}16 \\
0 \\
0\end{array}$ \\
\hline
\end{tabular}

* Detected by indirect immunofluorescence on rat tissue sections.

+Detected by indirect immunofluorescence on HEp2 cells.

$\ddagger$ Detected by counterimmunoelectrophoresis using soluble tissue extracts.

only one patient with primary biliary cirrhosis. The incidence of antibody to XR was significantly different between the groups (with primary biliary cirrhosis, eight of 51 or $16 \%$; without primary biliary cirrhosis zero of $35, p=0.034$ ).

Titre and immunoglobulin class of antimitochondrial antibody

Although there was little difference between the geometric mean titre of the IgG class antimitochondrial antibody in the patients with and without primary biliary cirrhosis, there was a significant higher geometric mean titre of IgM class antimitochondrial antibody in the patients diagnosed with primary biliary cirrhosis compared with that of patients without primary biliary cirrhosis $(p=0.012)$, although these IgM titres were low in both groups $(1 / 28$ with primary biliary cirrhosis; $1 / 16$ without primary biliary cirrhosis).

\section{Alkaline phosphatase activity and serum IgM value} There was no significant difference between the incidence of patients with a raised alkaline phosphatase activity in either group ( $88 \%$ with primary biliary cirrhosis; $43 \%$ without, $\mathrm{p}=0.08$ ), and similarly, a significant difference was not seen between the incidence of patients with a raised IgM value $(>3 \mathrm{~g} / \mathrm{l})$ in both groups ( $86 \%$ with primary biliary cirrhosis; $51 \%$ without, $\mathrm{p}=0.09$ ).

\section{Discussion}

The clinical importance of antimitochondrial antibody is unknown. Triger et $\mathrm{al}^{7}$ showed that most liver biopsy specimens from patients with antimitochondrial antibody but with no clinical signs of hepatocellular disease had normal histology or histology consistent with a diagnosis of primary biliary cirrhosis. Hodges $e t a^{8}$ also found that four of seven liver biopsy specimens from patients with antimitochondrial antibody but with no evidence of primary biliary cirrhosis showed normal histology, in another two the histology was not consistent with primary biliary cirrhosis, and in only one were there features of primary biliary cirrhosis. In contrast, James $e \mathrm{al}^{4}$ showed that all their patients with antimitochondrial antibody with normal liver function tests had liver biopsy histology consistent with primary biliary cirrhosis.

As liver biopsies were not carried out in patients without clinical or biochemical evidence of liver disease, investigations of other serological variables in the group of 86 patients with M2 antimitochondrial antibody were made. In our series antibody giving a multiple dot pattern on HEp2 cells was observed in $41 \%$ of patients with primary biliary cirrhosis but was absent in patients without primary biliary cirrhosis. Bernstein et al ${ }^{15}$ described this pattern as numerous nuclear dots all the same size varying from two to 17 per cell, distinct from nucleoli, and different from centromere staining in that the dots were larger, fewer in number, and were not seen in mitotic cells. This staining was sensitive to trypsin digestion and resistant to RNAase and DNAase, indicating that the antigen is a protein. This pattern was found in $13 \%$ of 110 patients with primary biliary cirrhosis in their series but not in patients with $\mathrm{HBsAg}$ positive and negative chronic active hepatitis or in 60 control subjects. Cas- 
sani et al $^{21}$ also described this pattern in $17 \%$ of patients with primary biliary cirrhosis and not in patients with other liver disease. This antibody has also been found in patients with primary biliary cirrhosis with the sicca syndrome, but as features of sicca syndrome were not investigated in our series we cannot substantiate this association. Antibody to a soluble cellular extract antigen XR obtained from saline extracts of rabbit thymus powder was detected in $16 \%$ of the patients with primary biliary cirrhosis and not in any other patients, and this antibody also seems to be a good marker for primary biliary cirrhosis, though Bernstein et al ${ }^{15}$ also described this antibody in $24 \%$ of patients with $\mathrm{HBsAg}$ negative chronic active hepatitis. We found this antibody in only $4 \%$ of a series of $50 \mathrm{HBsAg}$ negative patients with chronic active hepatitis (unpublished data).

The IgM class of antimitochondrial antibody was helpful in distinguishing between patients with and without primary biliary cirrhosis. A significantly greater number of patients with primary biliary cirrhosis had IgM class of antimitochondrial antibody of titre $>1 / 20$ than those without the disorder. It has been suggested that the specificity for primary biliary cirrhosis increases with antimitochondrial antibody titre, ${ }^{8}$ but in our study this was true for IgM titre but IgG did not help in discriminating between patients with and without primary biliary cirrhosis.

Although only $59 \%$ of patients with M2 type antimitochondrial antibody were diagnosed as having primary biliary cirrhosis, the presence within this group of IgM class antimitochondrial antibody, antibody giving a multiple nuclear dot pattern on HEp2 cells, and antibody to XR, enhanced the diagnostic value of M2 type antimitochondrial antibody for primary biliary cirrhosis.

We thank Mr SK Conlan for technical help and Mrs Maureen Collins for typing the manuscript.

\section{References}

1 Baum H, Berg PA. The complex nature of mitochondrial antibodies and their relation to primary biliary cirrhosis. Semin Liver Dis 1981;1:309-21.

2 Doniach D, Roitt IM, Walker JG, Sherlock S. Tissue antibodies in primary cirrhosis, active chronic (lupoid) hepatitis, cryptogenic cirrhosis and other liver diseases and their clinical implications. Clin Exp Immunol 1966;:237-62.
3 Klatskin G, Kantor FS. Mitochondrial antibody in primary biliary cirrhosis and other diseases. Ann Intern Med 1972; 77:533-41.

4 James O, Macklon AF, Watson AJ. Primary biliary cirrhosis-a revised clinical spectrum. Lancet 1981 ; i:1278-81.

5 Munoz LE, Thomas HG, Scheuer PJ, Doniach D, Sherlock S. Is Mitochondrial antibody diagnostic of primary biliary cirrhosis? Gut 1981;22:136-40.

6 Tael BG, Schalm SW, tenKate FWJ, Hermans J, Geertzen RGM, Feltkamp BEW. Clinical diagnosis of primary biliary cirrhosis: a classification based on major and minor criteria. Hepatogastroenterol 1983;30:178-82.

7 Triger DR, Charlton CAC, Milford-Ward A. What does the antimitochondrial antibody mean? Gut 1982;23:814-8.

8 Hodges JR, Hall AJ, Wright R. Primary biliary cirrhosis and antimitochondrial antibodies. Lancet 1981 ;ii:144.

9 Hamblin TJ. Significance of antimitochondrial antibodies. Lancet 1981;ii:1411-2.

10 Lauristen $\mathrm{K}$, Diederichen. Arthritis in patients with antimitochondrial antibodies. Scand J Rheumatol 1983;12:331-5.

11 Baum H, Berg PA. The complex nature of mitochondrial antibodies and their relationship to primary biliary cirrhosis. In: Jones EA, ed. Seminars in liver disease. Vol IV. New York: Thieme-Stratton, 1981:309-21.

12 Berg PA, Homberg JC, Bottazzo GF, Doniach D. Clinical significance of mitochondrial antibodies in relationship to liver disease. Lancet 1981 ;ii:804.

13 Berg PA, Klein R. Clinical and prognostic relevance of different mitochondrial antibody profiles in primary biliary cirrhosis (PBC). Mol Aspects Med 1985;8:235-47.

14 Bernstein RM, Callender ME, Neuberger JM, Hughes GRV, Williams $R$. Anticentromere antibody in primary biliary cirrhosis. Ann Rheum Dis 1982;41:612-4.

15 Bernstein RM, Neuberger JM, Bunn CC, Callender ME, Hugh GRV, Williams R. Diversity of autoantibodies in primary bili ary cirrhosis and chronic active hepatitis. Clin Exp Immunfor 1984;55:553-60.

16 Powell F, Schroeter AR, Dickson ER. Antinuclear antibodies in primary biliary cirrhosis. Lancet 1984;i:288-9.

17 Bunn CC, Gharavi AE, Hughes GRV. Antibodies to extractable nuclear antigens in 173 patients with DNA-binding positive SLE: An association between antibodies to ribonucleoprotein and $\mathrm{Sm}$ antigens observed by counterimmunoelectrophoresis. $J$ Clin Lab Immunol 1982;8:13-17.

18 Akzuki M, Boehm-Truitt MJ, Kassan SS, Steinberg AD, Chused TM. Purification of an acidic nuclear protein antigen and demonstration of its antibodies in subjects of patients with sicca syndrome. J Immunol 1977;119:932-8.

19 Alspaugh MA, Tan EM. Antibodies to cellular antigens in Sjogrens syndrome. J Clin Invest 1975;55:1067-73.

20 Labro MT, Andrieu M-C, Weber M, Homberg JC. A new pattern of non-organ- and non-species-specific anti-organelle antibody detected by immunofluorescence: the mitochondrial antibody number 5. Clin Exp Immunol 1978;31:357-66.

Requests for reprints to: Dr SA McMillan, Immunology Laboratory, The Laboratories, Belfast City Hospital, o Belfast BT9 7AD, Northern Ireland. 